\title{
Design Of Web-Based School Library Information System Using YII Framework In SMA Karya Pembangunan Ciwidey
}

\author{
Johni S Pasaribu ${ }^{* 1}$, Po Abas Sunarya ${ }^{2}$ \\ ${ }^{1}$ Politeknik Piksi Ganesha Informatics Engineering, ${ }^{2}$ Program Studi Magister Teknik Informatika \\ Fakultas Sains dan Teknologi Universitas Raharja \\ E-mail: ${ }^{* 1}$ johni_0106@yahoo.com, ${ }^{2}$ abas@ raharja.info
}

\begin{abstract}
The rapid development of the computer world that brings every individual or group of people will use information and communication technology in every activity. Likewise in the world of education, including libraries that utilize information and communication technology in managing the process of borrowing and returning library books. The benefits of making a webbased library information system include being able to save time where there is no need for manual recording, making it easier to find book data or library members, making it easier in making book loan reports and other reports and other benefits. The research method used is Research and Development $(R \& D)$. The making of software is done by a waterfall model consisting of: (1) needs analysis, (2) design, (3) implementation, and (4) testing. Then UML visual modeling is used which is the standardization of modeling language for object-oriented software development. The expected results of this study produce a web-based library information system using the YII Framework with MVC (Model View Controller) method in SMA Karya Pembangunan Ciwidey that can solve existing problems. The formulation of the problem of this research is how to build a library information system in SMA Karya Pembangunan Ciwidey so that it can present accurate and efficient information. The purpose of this research is to produce a library information system.
\end{abstract}

Keywords - School Library, System Information, Web-Based.

\section{INTRODUCTION}

With the rapid development of information and communication technology in this globalization era, it will have an impact on library management, where a school that applies information and communication technology in its school can improve services to library users. With information and communication technology in the library, it is expected to be able to provide maximum service to library users and minimize errors in data processing.

The library was established to meet the information needs of the community, so it is a place that provides facilities and sources of information and becomes a learning center ${ }^{[1]}$. In practice, libraries as managers of information and knowledge must be able to use and utilize information technology to the fullest. There are several reasons why libraries should utilize information and communication technology: (1) libraries must be able to provide services in quantity, (2) libraries are able to provide services in the use of collections together, (3) libraries are able to make effective human resources, (4) libraries use time efficiency, and (5) the library is able to manage the diversity of information it has ${ }^{[2]}$. In an effort to improve service performance, the use of information systems is an appropriate alternative or solution. Reasons for using information systems include: 1) greater processing speed 2) accuracy and better consistency, 3) achieving information faster, 4) reducing costs, 5) better security ${ }^{[3]}$.

The school library functions as a place to read where the library is now increasingly less in demand by students in places to read and look for book literature. This is due to the presence of other information media such as the internet which through this media will make it easier to search various kinds of information and reading sources. The impact of this internet information media was also felt by the SMA Karya Pembangunan Ciwidey Library where the students were less interested in reading and borrowing books from the library besides having certain assignments from the teacher which required students to borrow books from the library while the library had a 
large collection of books. Other problems are the SMA Karya Pembangunan Ciwidey Library in serving borrowers and book readers experiencing problems in managing administrative data in the library, namely errors in recording serial numbers in the master book, errors in managing borrowing data and book returns. In addition, students also have difficulty in finding books to be borrowed, where students must find the book carefully on the shelf, besides that there is no information whether the book is still there or does not exist because it is being borrowed by someone else. identified:

Based on the background that has been described, the causes of the problem can be

1. Recording and managing data requires a long time and is not effective because it still uses simple media.

2. Difficult to find member data, book data, and transactions due to lack of organized data.

3. Making a report requires a long time because the user must do it manually from data collection to processing.

4. Data security is less guaranteed because it is physical so that data can be lost or manipulated. The objectives to be achieved are as follows:

1. Facilitate the recording and management of data so that it can improve time efficiency.

2. Facilitate the search for data books, members, and library transactions.

3. Assist users in making reports.

Existing similar research is research conducted by Minarni and Fazril Hadi Saputra with the title Web-Based Library Information System in Padang Health Polytechnic ${ }^{[4]}$. The system designed here is book borrowing, book return, member data input, circulation and book search. The research aims for the Politeknik Kesehatan Padang Library to serve students of the Padang Health Polytechnic and visitors who come directly to the library or who access via the internet get information quickly and accurately. Similar research was also carried out by Dani Eko Hendrianto with the title Making Website Based Library Information System at SMPN 1 Donorojo Pacitan Regency ${ }^{[5]}$. The research aims to produce a library information system in improving the services and performance of library staff in terms of managing library administration data and accelerating student loan and book return transactions. From the research conducted by Dani Eko Hendrianto, it can be concluded that his research resulted in a web-based information system that can be used by library staff of SMPN 1 Donorojo in managing and inputting book data to speed up the process of searching and compiling data in book collections, magazines, research journals, member data collection, data collection of loans and repayments and can accelerate the process of borrowing and book repayment transactions conducted by students of SMPN 1 Donorojo, Pacitan Regency. Another relevant study is the Web-Based School Library Information System with CodeIgniter and PostgreSQL Framework in SMA Negeri 1 Ngaglik by Punky Indra Permana, Yogyakarta State University ${ }^{[6]}$. The purpose of this research is to create a school library information system and determine the level of eligibility in terms of functionality, security, usability, maintainability, portability and efficiency. The results obtained in this study can be concluded that by using the Codeigniter framework, producing good quality software in terms of functionality, security, usability, maintainability, portability and efficiency.

The relevant research equation for this research is about software testing methods for manufacturing information systems. The first research focuses on creating and testing information systems for polytechnic library services. The second relevant research focuses on creating and testing information systems for junior high school libraries. Then the third research focuses on creating and testing information systems for high school library services. While the difference is the PHP framework and the quality standards used. This study uses the YII Framework. YII is a high performance component-based PHP framework for large-scale Web application development. The results of this software can be used in the SMA Karya Pembangunan Ciwidey Library so that this new system can facilitate the recording and management of data so that it can improve time efficiency. In this information system, library staff / managers carry out data processing and report to the leadership easily and more accurately. The author tries to create an information system that makes it easier for students to find book data, book borrowing information and submit library member registration that can be done using the internet 


\section{RESEARCH METHODS}

The research method used in this research is the Research and Development method. Research and Development (R\&D) is a research method used to make or produce products to test the effectiveness of these products ${ }^{[7]}$. The software development approach used in this study is the classic life cycle model or the waterfall model. The classic life cycle model uses a systematic and sequential approach to the level of system progress throughout all analysis, design, code, testing, and maintenance ${ }^{[8]}$. This study uses a waterfall development model that is combined with the prototyping paradigm to help researchers easily define user needs and anticipate changing needs in the software development process ${ }^{[9]}$. Prototyping is used as a technique that can be implemented in the context of other process models, although the prototyping paradigm can be used as a standalone process model ${ }^{[10]}$. The prototyping paradigm can help developers and users better understand what needs to be built when the requirements are still general. The phases in the Waterfall Model according to Sommerville's reference ${ }^{[11]}$ are as follows:

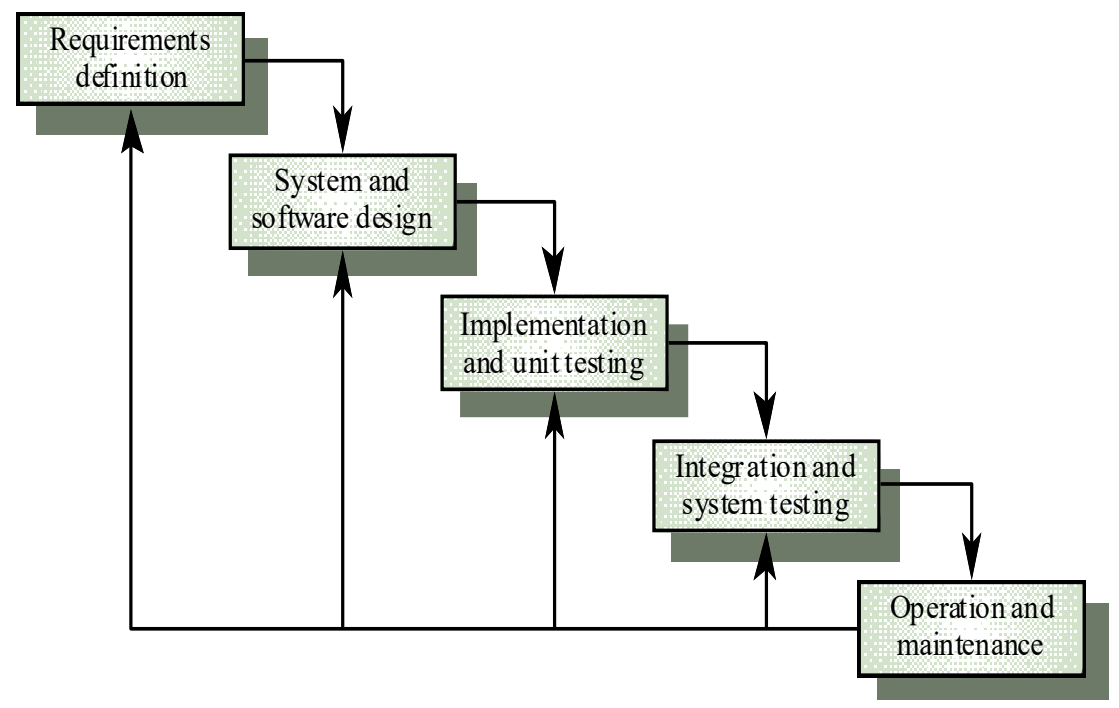

Figure 1. Waterfall Model Sommerville

1. Requirements analysis and definition

Gathering the complete requirements and then analyzed and defined the needs that must be met by the program to be built. This phase must be done in full to be able to produce a complete design. Needs analysis conducted by researchers is in the form of field studies (observations), interviews, and relevant research searches (literature). The results obtained are in the form of user requirements or data related to user desires and software requirements (software requirements).

2. System and software design

The design is done after the complete needs analysis is collected. The System and software design stage is actually a multi-step process that focuses on the four attributes of a different program; data structure, software architecture, interface representation, and procedural detail (algorithm). This stage produces the system requirements.

3. Implementation and unit testing

The completed system and software design stage is then continued to the language translation phase into codes using a specific programming language that can be understood by computers. The program is built directly tested externally to find out the errors that occur and ensure that the input given to the system is able to provide the actual output and according to the user's desired.

4. Integration and system testing

The uniting of the program units is then tested as a whole (system testing). System testing that researchers use in testing the software made is usability, functionality, and correctness.

5. Operation and maintenance

Operate programs in their environment and carry out maintenance, such as adjustments or changes due to adaptation to the actual situation. 
A software framework is a basic design that can be used and developed for an application system or subsystem. A software framework provides a collection of basic code that can help in the process of developing and combining different components in a software ${ }^{[12]}$. A programming framework can simplify the process of compiling program function codes by reducing code operations that are repetitive ${ }^{[13]}$. Because the purpose of the framework is to help with general activities, many frameworks provide libraries for database access, session data management, etc. ${ }^{[14]}$. The web programming framework based on the PHP-Hypertext Preprocessor programming process simplifies the application development process, helping to structure the functions of a system faster because it does not have to write it from scratch. This can also improve the quality and stability of programming code structures ${ }^{[15]}$. The framework significantly reduces the time, resources, effort needed to develop and manage web applications. In addition, the framework is an open architecture based on common standards used ${ }^{[16]}$.

PHP is a server-side programming language specifically designed for web-based application development. Many advantages of the PHP programming language, among others in the aspects of performance, scalability, portability, open source, and especially to connect and manipulate a database ${ }^{[17]}$. Database management is done by Structure Query Language (SQL). Some studies state that traditional database query languages are not easy to use for inexperienced database technology users, as a consequence because their interactions are based on textual languages, such as SQL ${ }^{[18]}$.

In system design (design pattern), it is well known one of them is the Model-ViewController approach ${ }^{[19]}$, which can make it easy in the process of developing and managing an application, because ${ }^{[20]}$ : (1) display (output) applications can change drastically without changing data structure and business logic, (2) applications can be easily managed / used with different interfaces, for example multi-language, or setting different user access rights.

The Model-View-Controller design pattern approach is an easy way to develop interactive software system architectures ${ }^{[21]}$. Also known as the Presentation / Abstraction / Control (PAC) design pattern, the main idea is to separate the interface and the data below it ${ }^{[22]}$. The Model-ViewController pattern has proven to be effective for creating and organizing modular applications ${ }^{[23]}$.

Yii is a high-performance component-based PHP framework for large-scale Web application development. It provides maximum reusability in Web programming and can accelerate the development process significantly ${ }^{[2]}$. Yii Framework itself is a framework that has the concept of solving a problem no longer seen from how the procedure, but from what objects are related to solve the problem ${ }^{[25]}$. The Yii Framework implements a model-view-controller (MVC) design pattern that is widely adopted in web programming. MVC aims to separate business logic from user interface considerations so that developers can more easily change each part without affecting the others ${ }^{[26]}$.

Yii implements a model-view-controller (MVC) design pattern, which is widely adopted in Web programming. MVC aims to separate business logic from user interface considerations so that developers can more easily change each part without affecting the others. In MVC, the model describes information (data) and business rules; view contains elements of user interface such as text, form input; while the controller manages communication between models and views. In addition to the MVC implementation, Yii also introduces a front controller, called Application, which encapsulates the execution context for processing a request. The application collects some information about the user's request and then sends it to the appropriate controller for further handling. The following diagram shows the static structure of an Yii application according to the official Yii Framework website: 


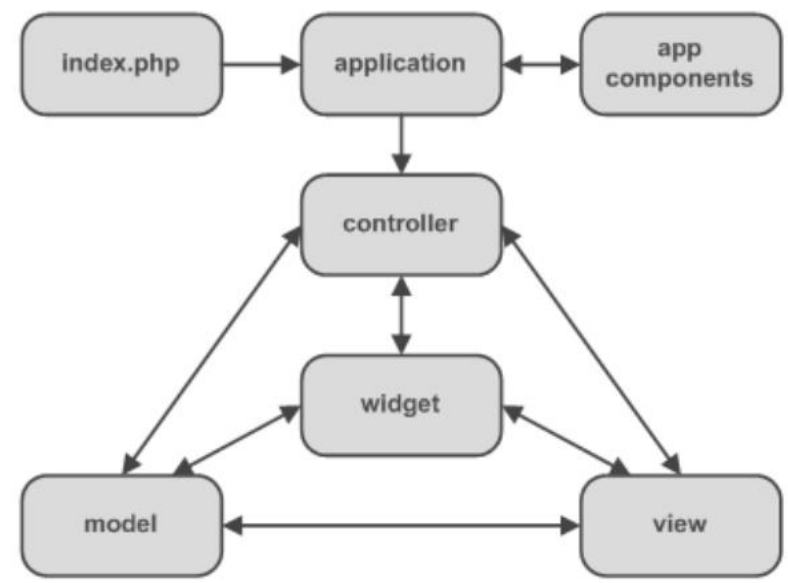

Figure 2. The static structure of the Yii application (Sharive, 2013).

\section{RESULTS AND DISCUSSION}

Library information system development begins with an analysis of system requirements. This analysis is needed so that the development process is right on target and functioned properly as a library information system for SMA Karya Pembangunan Ciwidey. Analysis and design of web-based library information systems in SMA Karya Pembangunan contains use case diagrams, class diagrams and activity diagrams. Also given the implementation of the system that has been made.

\subsection{Analysis and Design}

The minimum requirements that must be present according to the results of observations and interviews are as follows in Tabel $1^{[27]}$. Functional requirements as in Tabel 1 and nonfunctional requirements as in Tabel 2 of web-based library information system software in SMA Karya Pembangunan are as follows:

Table 1. Functional Needs

\begin{tabular}{lll}
\hline \hline No & Functional Needs & What the actor does \\
\hline \hline 1 & $\begin{array}{l}\text { The system must log in before it can } \\
\text { be accessed }\end{array}$ & Library staff entered the system \\
2 & $\begin{array}{l}\text { The system must be able to manage } \\
\text { books }\end{array}$ & Library staff manage book data \\
3 & $\begin{array}{l}\text { The system must be able to manage } \\
\text { members }\end{array}$ & Library staff manage member data \\
4 & $\begin{array}{l}\text { The system must be able to manage } \\
\text { transactions } \\
\text { The system must be able to provide } \\
\text { reports }\end{array}$ & Library staff make a report \\
\hline \hline
\end{tabular}

Table 2. Non-Functional Needs

\begin{tabular}{lll}
\hline \hline No & Non-Functional Needs & Description \\
\hline \hline 1 & Operational & Windows $732 / 64$ bit Operating System; \\
& Computer Specifications: Processor \\
& (Pentium 4 Dualcore 1.6 Ghz), RAM: \\
& $512 \mathrm{MB}$, VGA: 256MB, Monitor: 14 \\
& 'inch, Keyboard: Standard Type USB \\
& Cable 101/102 key, Mouse: Type USB \\
& Cable with optical; Web Browsers: \\
& Google Chrome, Internet Explorer \& \\
& Mozilla Firefox; Web Server: Apache; \\
& Database Server: MySQL; Yii \\
& Framework version 1.1; Sublime Text
\end{tabular}


3; XAMPP version 1.7 .3 with

PhpMySQL support.

2 Security

The application system and database are equipped with a password; equipped with CCTV in the reading room and bag storage

3 Information

Used to display the procedures for registering new members; used to display information when a user enters an incorrect password; provide a library member identity report is complete

\subsection{Use Case Diagram}

The use case diagram is used to find out what functions exist in a system and who has the right to use these functions. Use Case Diagrams consist of actors and interactions that they do in a system. In the development of use case diagram software is used to explain the relationships and actors in the form of input or output in a system. Use case diagrams depict actors and relationships with their respective functions. In the information system developed there are actors namely library staff. Library staff has functions including managing book data, managing member data, managing transaction data, and making reports. The following contains a use case diagram for a web-based library information system at SMA Karya Pembangunan.

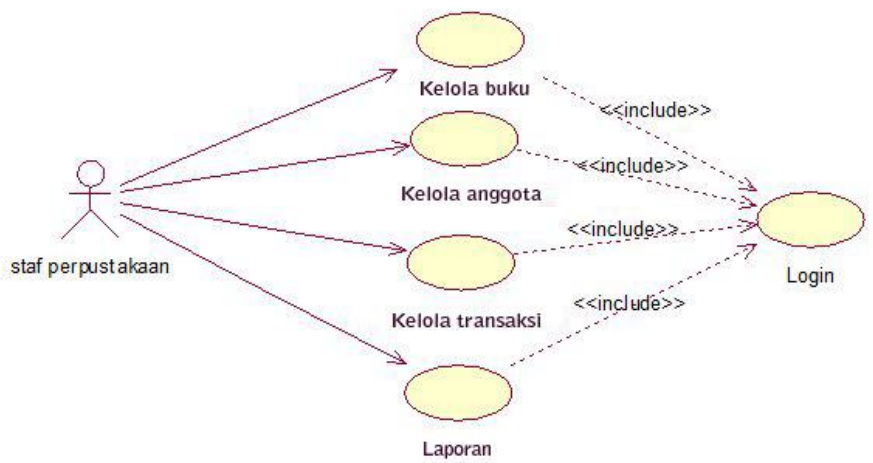

Figure 3. Use Case Diagram

\subsection{Class Diagram}

Class Diagram contains a description of the structure and explanation of classes, packages and objects and relationships with each other such as associations, inheritance and others in a system. Class diagram of the library information system can be seen in Figure 4 as follows:

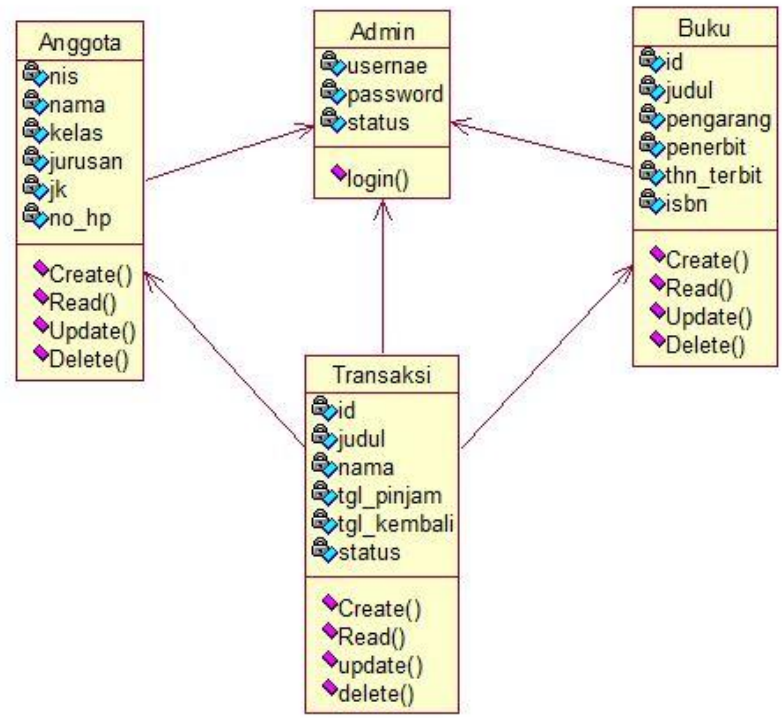

Figure 4. Class Diagram 


\subsection{Activity Diagram}

Activity Diagram illustrates the workflow or activity of a system or business process. Based on the use case diagram that has been made, the activity diagram illustrated can be seen as follows:

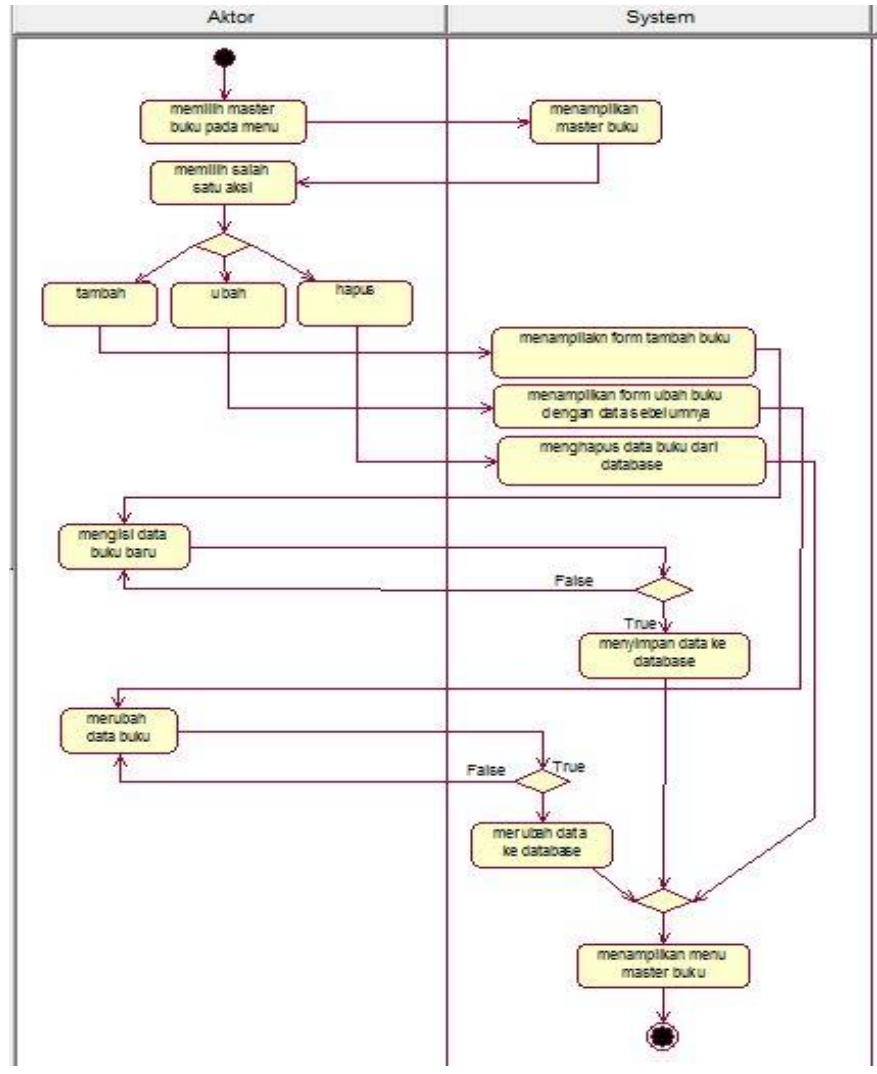

Figure 5. Activity Diagram Manage Books

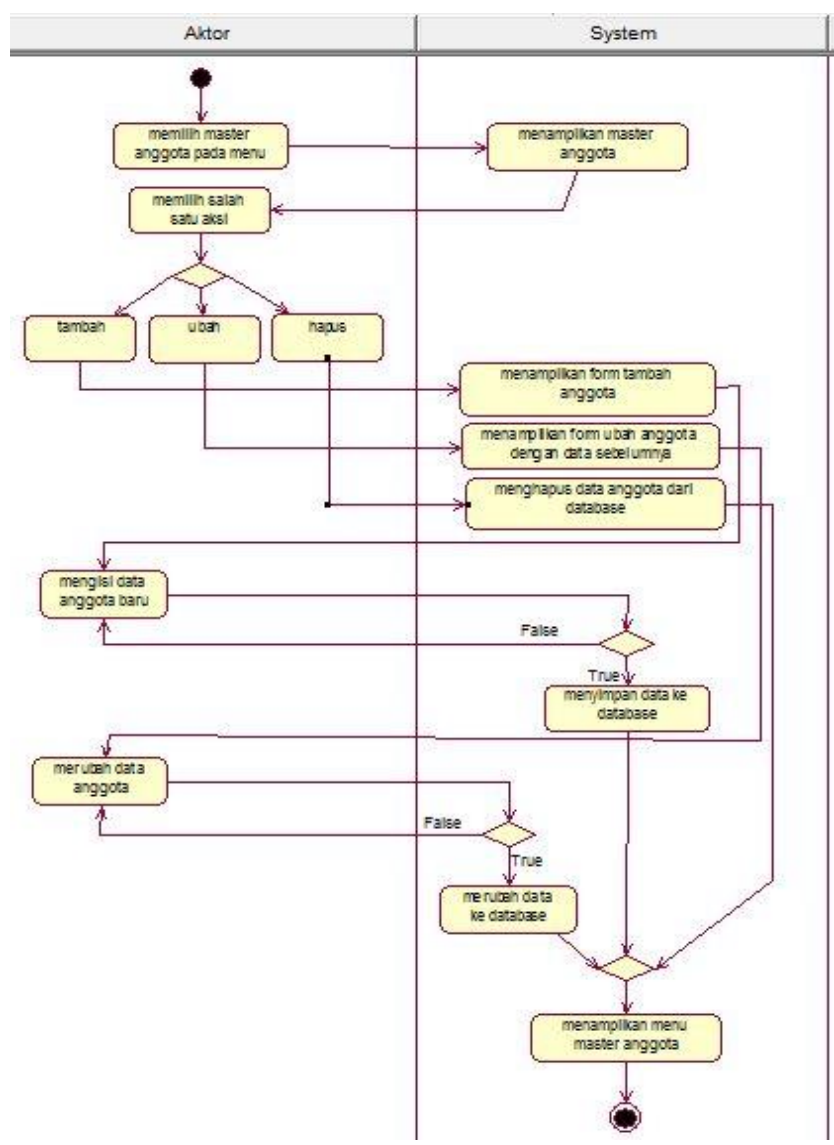

Figure 6. Activity Diagram Manage Members 


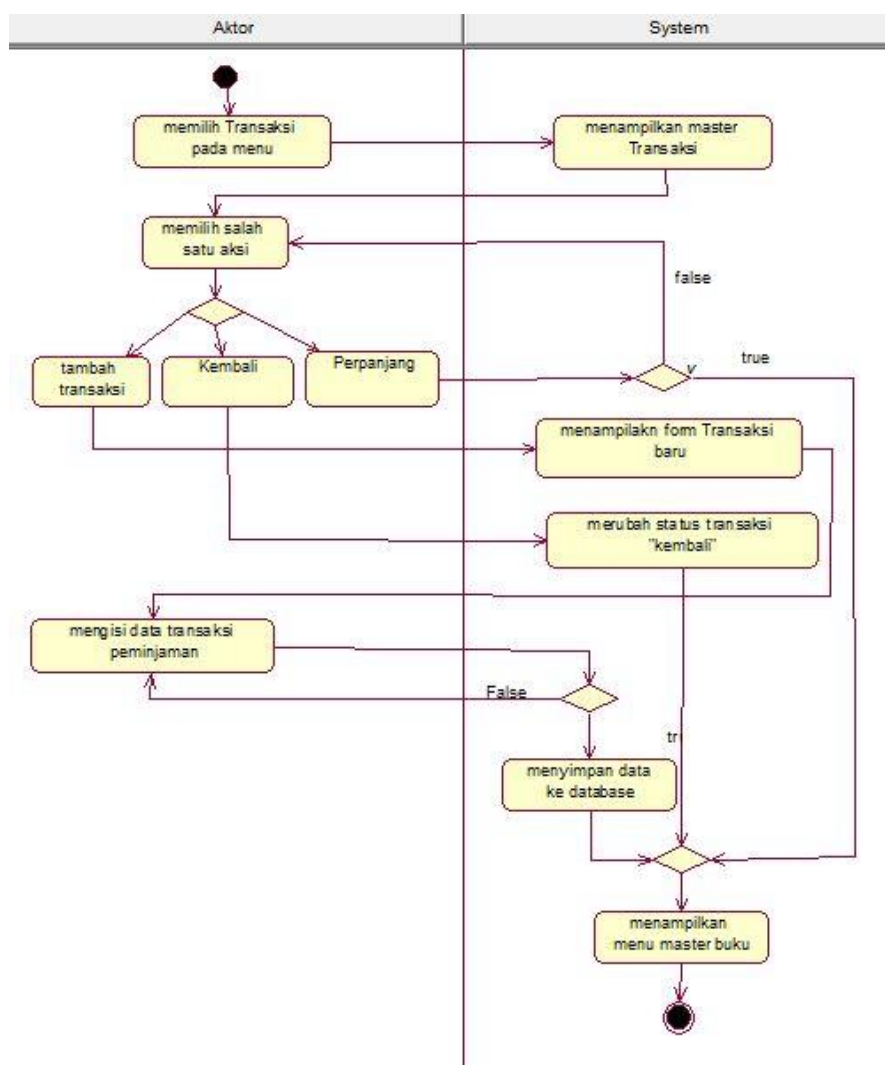

Figure 7. Activity Diagram Manage Transactions

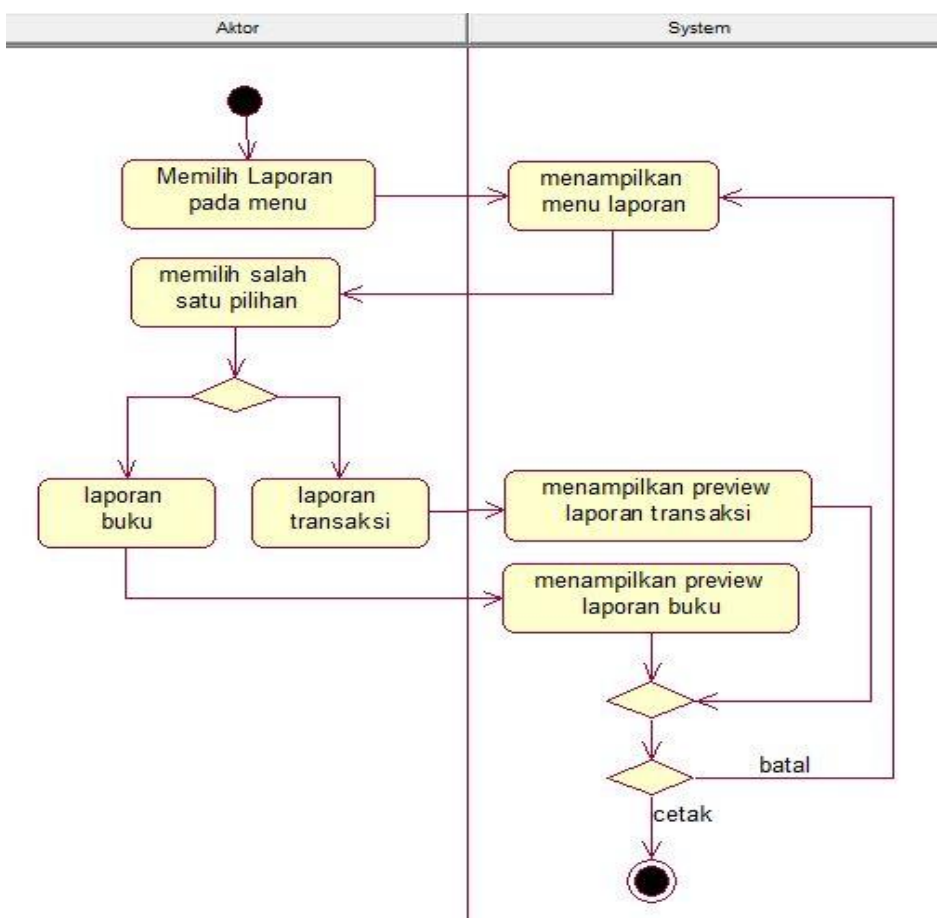

Figure 8. Activity Diagram Report

\subsection{Implementation}

The design of the application makes it easy for users to use this system. Figure 9 The Login Screen Dialog functions so that potential users (library staff) can register themselves. As for the description: enter the Username and enter the Password, then click LOGIN to go to the start page. 


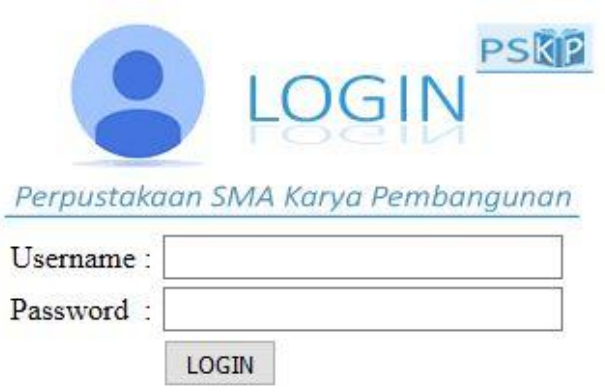

Figure 9. Login Screen Dialog

After logging in, the user will enter The Home Screen Dialog. The Home Screen Dialog is the Start Page to enter the Book Master Page, Member Master Page, Transaction Master Page, and Report Master Page.

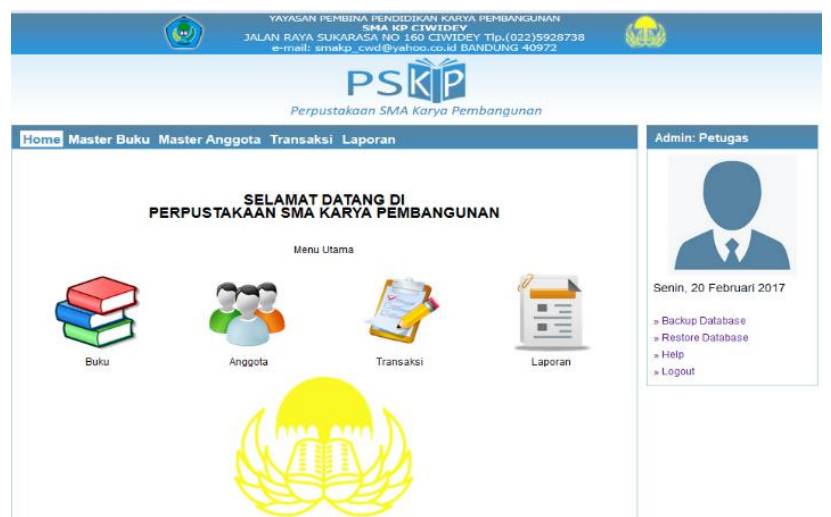

Figure 10. The Home Screen Dialog

The Book Master Screen Dialog functions to display a list of available books. There are several functions provided, namely: Create New Book Data (add book), Book Details (see details about books), Edit Books (fill in details about books) and Delete Books (delete book data in the information system). Figures 11 through 15 show The Book Master Screen Dialog and its functions.

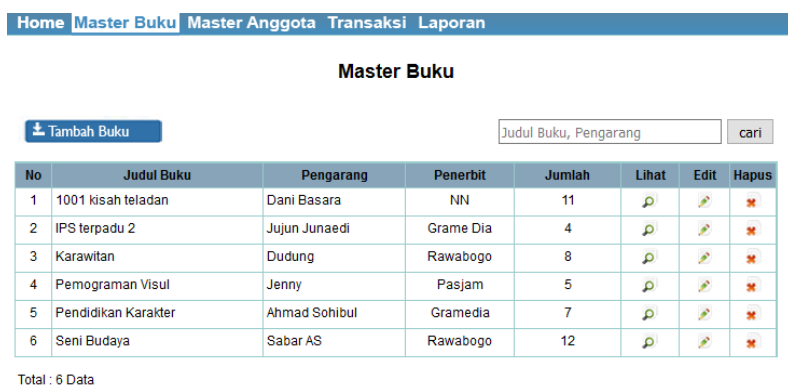

Figure 11. The Book Master Screen Dialog

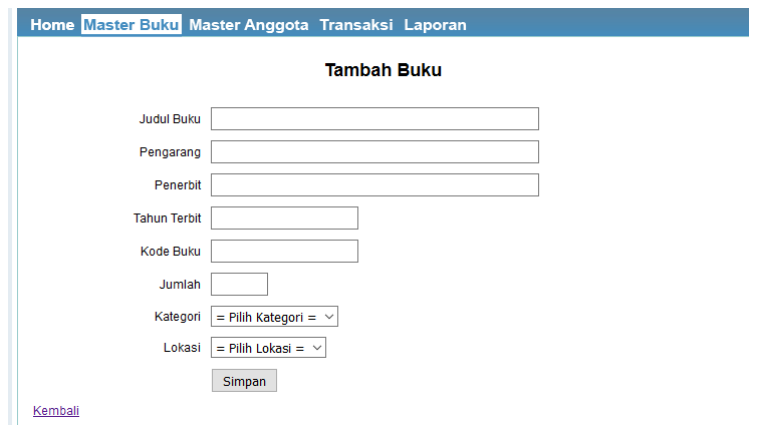

Figure 12. The Add Book Screen Dialog 


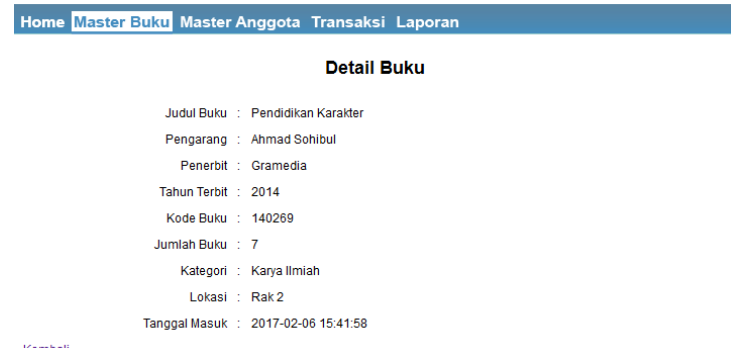

Figure 13. The Book Details Screen Dialog

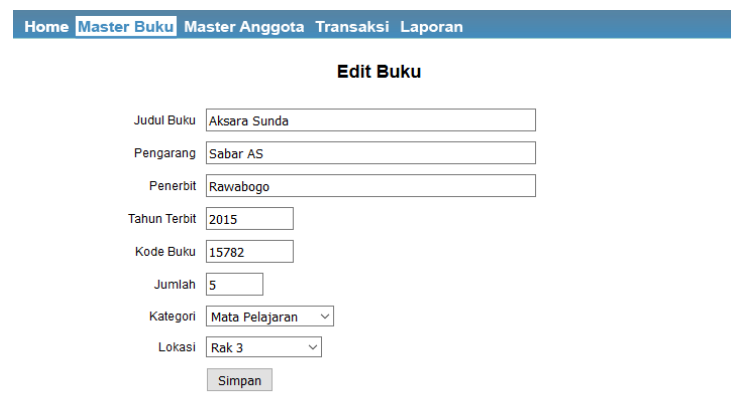

Figure 14. The Edit Book Screen Dialog

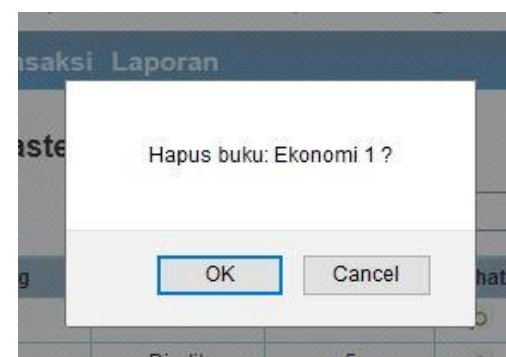

Figure 15. The Delete Book Screen Dialog

The Member Master Screen Dialog functions like the Book Master Screen Dialog, where The Member Master Screen Dialog functions to display the list of available library members. There are several functions provided, namely: Create New Members (add members), Member Details (see details about members), Edit Members (fill in details about members) and Delete Members (delete member data in the information system).

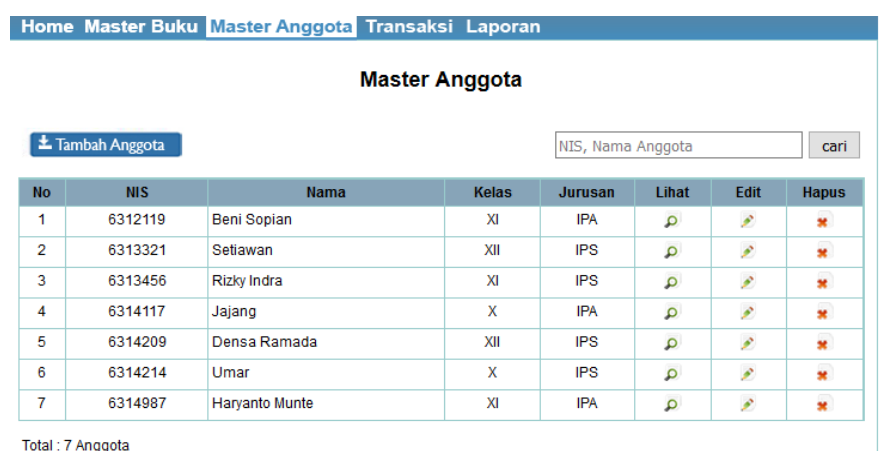

Figure 16. The Member Master Screen Dialog

The Transaction Screen Dialog contains the Borrowing Transaction Screen Dialog and the Return Transaction Screen Dialog. The Borrowing Transaction Screen Dialog functions to make book loan data, namely: the title of the book, the borrower, the date of the loan, the date of return, being late (if there is a penalty), the status of the book returning or renewing. 


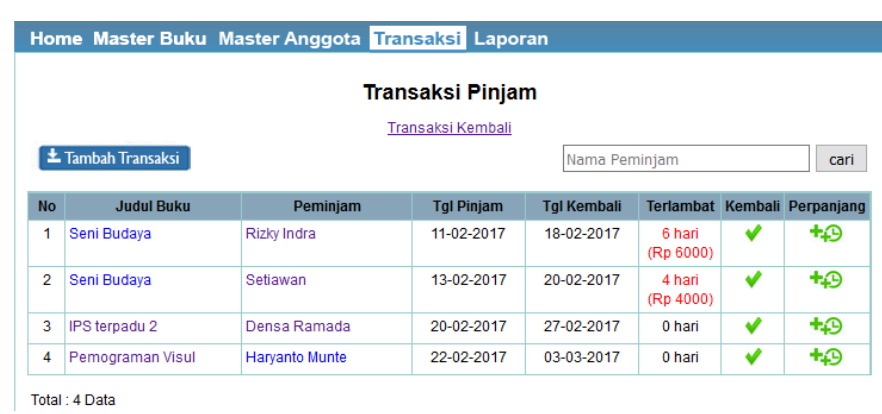

Figure 17. The Borrowing Transaction Screen Dialog

Likewise, the Return Transaction Screen Dialog functions to make a book return transaction, namely: book title, borrower, borrowed date, return date, status (back) or not (cancel).

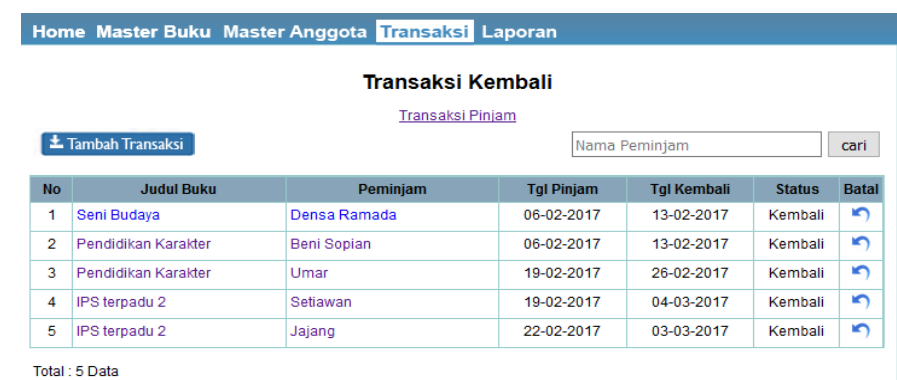

Figure 18. The Return Transaction Screen Dialog

The Report \& Print Screen Dialog functions to report book and member data and can print them. This Report \& Print Screen Dialog contains a Book Report Screen Dialog and Transaction Report Screen Dialog.

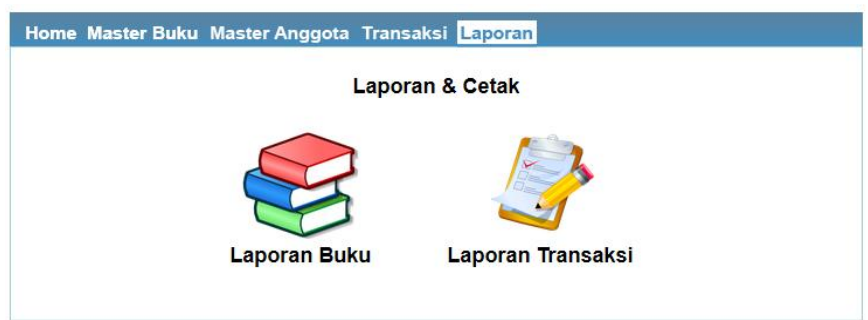

Figure 19. The Report \& Print Screen Dialog

The Book Report Screen Dialog contains a list of book reports (book code, book title, author, publisher, year of publication, and number of books. This book list report can be printed.

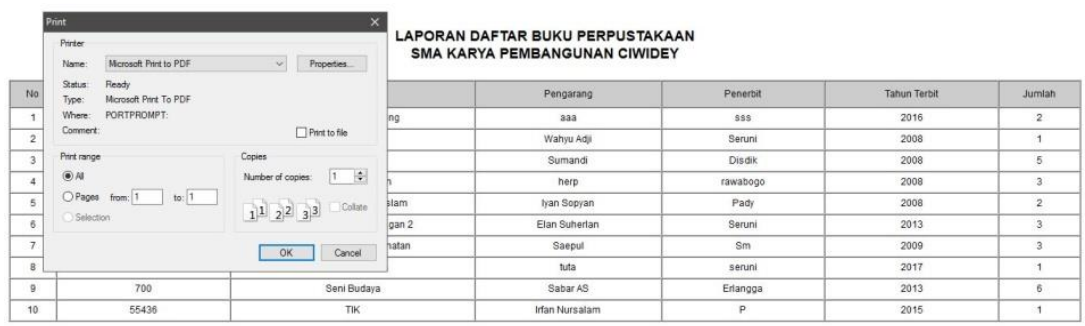

Figure 20. The Book Report Screen Dialog

The Transaction Report Screen Dialog contains a report on borrowing or returning books (book title, borrower's name, borrowed date, return date, and status). This Transaction Report can be printed and can be specially selected Loan Transaction Report or Return Transaction Report. 


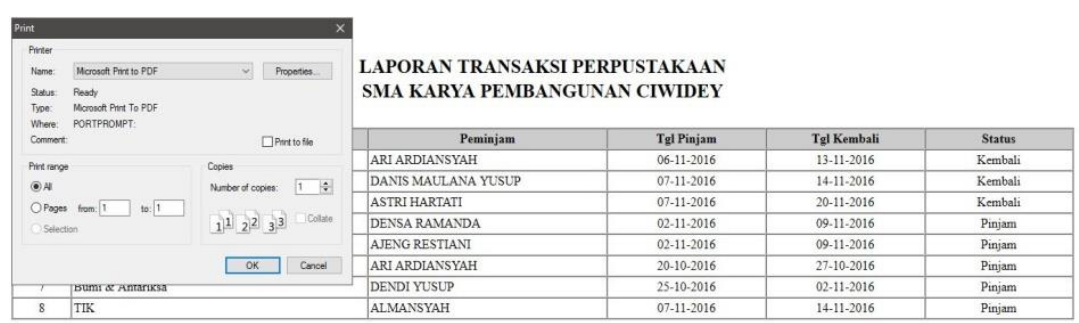

Figure 21. The Transaction Report Screen Dialog

\section{CONCLUSION}

Based on the results of research and discussion conducted, the authors can draw some conclusions as follows:

1. With this software, the SMA Karya Pembangunan Ciwidey is easier to record and manage data so that the time is more efficient.

2. With this software, it also makes it easier to search book data, member data, and transaction data in the library (borrow and return books).

3. Making reports such as book reports, member reports and transaction reports (borrowing and returning books) can also be done easily. Also can be done printing the report.

4. Data security can be stored and maintained properly because of the security protection that is done in stages in its access.

\section{SUGGESTED}

Based on the research that has been done, the following suggestions can be given:

1. This software needs to be developed further so that there is integration between the library members' data and the data of students at the school where students who are still active and students who have graduated from the school will be able to know.

2. Adding features is needed to get more complex applications and provide solutions to every problem encountered. Some examples of features in the future development such as the addition of barcode features to read the identity of the book.

3. It is also necessary to add other features in the form of making access rights for SMA Karya Pembangunan Ciwidey Library members.

\section{REFERENCES}

[1] NS, Sutarno. (2006). Perpustakaan dan Masyarakat. Jakarta: Sagung Seto, 34.

[2] Saleh. (2006). Penyelenggaraan Perpustakaan Sekolah. Jakarta: PT. Hidakarya Agung, 1.

[3] Kristanto, Andri. (2004). Rekayasa Perangkat Lunak (Konsep Dasar). Yogyakarta: Gava Media.

[4] Minarni \& Saputra, Fazril Hadi. (2011). Sistem Informasi Perpustakaan Berbasis Web Pada Politeknik Kesehatan Padang. Jurnal Teknologi Informasi \& Pendidikan, 3 (1), 102-109.

[5] Hendrianto. (2014). Pembuatan Sistem Informasi Perpustakaan Berbasis Website Pada Sekolah Menengah Pertama Negeri 1 Donorojo Kabupaten Pacitan. IJNS - Indonesian Journal on Networking and Security, 3 (4), 57-64.

[6] Indra Permana, Punky. (2013). Sistem Informasi Perpustakaan Sekolah Berbasis Web dengan Framework Codeigniter dan PostgreSQL di SMA Negeri 1 Ngangklik. Skripsi Teknik Informatika Universitas Negeri Yogyakarta, 39-41.

[7] Sugiyono. (2014). Metode Penelitian Kuantitatif, Kualitatif, dan R\&D. Bandung: Alfabeta, CV., 311.

[8] Pressman, Roger S. (2010). Rekayasa Perangkat Lunak: Pendekatan Praktisi (Buku 1). Yogyakarta: Andi Offset, 28.

[9] Munnasar, Nabil Muhammad Ali \& Govardhan, A. (2010). A Comparison Between Five Models Of Software Engineering. IJCSI International Journal of Computer Science, 7(5), 95 97. 
[10] Pressman, Roger S. (2010). Rekayasa Perangkat Lunak: Pendekatan Praktisi (Buku 1). Yogyakarta: Andi Offset, 43.

[11] Pasaribu, Johni S. (2016). Implementasi Sistem Pendukung Keputusan Menggunakan Logika Fuzzy untuk Penerimaan Beasiswa di Poltek Piksi Ganesha Bandung. Proceeding SENTIKA 2016, 80-89.

[12] Paikens, A., \& Arnicans, G. (2008). Use of Design Patterns in PHP-Based Web Application Frameworks. Department of Computing University of Latvia.

[13] Upton, D. (2007). CodeIgniter for Rapid PHP Application Development. Birmingham: Packt Publishing.

[14] DocForge. (2010). Web Application Framework. Retrieved from http://docforge.com/wiki/Web_application_framework.

[15] Yicheng, L. (2011). Development of a Blog System Using CodeIgniter Framework. Finland: Oulu University of Applied Sciences.

[16] Shan, T. C., \& Hua, W. W. (2006). Taxonomy of Java Web Applications Frameworks. IEEE International Conference on e-Business Engineering (ICEBE'06).

[17] Supaartagorn, C. (2011). PHP Framework For Database Management Based On MVC Pattern. International Journal of Computer Science \& Information Technology (IJCSIT), 3(2), 251-258.

[18] Avensano, L., Canfora, G., De Lucia, A., \& Stefanucci, S. (2002). Understanding SQL Through Iconic Interfaces. Computer Software and Applications Conference (COMPSAC), 703-708.

[19] Buschmann, F. (1996). Pattern-Oriented Software Architecture: A System of Patterns. 123168.

[20] Leff, A., \& Rayfield, J. T. (2001). Web-Application Development Using the Model/View/Controller Design Pattern. Enterprise Distributed Object Computing Conference, 2001. EDOC '01. Proceedings. Fifth IEEE International, 118-127.

[21] Krasner, G. E., \& Pope, S. T. (1988). A Cookbook for Using the Model-View-Controller User-Interface Paradigm in Smalltalk-80. Journal of Object-Oriented Programming, SIGS Publication, 26-49.

[22] Coutaz, J. (1987). PAC, An Object-Oriented Model for Dialog Design. Proceedings of Human-Computer Interaction (INTERACT), Elsevier Science Publishers, 431-436.

[23] Hofmeister, C., Nord, R. L., \& Soni, D. (2000). Applied Software Architecture. AddionWesley.

[24] Pasaribu, Johni S. (2017). Penerapan Framework YII Metoda MVC Dalam Pembangunan Sistem PPDB Berbasis Web di SMP BPPI Baleendah Kabupaten Bandung. Jurnal Ilmiah Teknologi Informasi Terapan JITTER, 3(2), 154-163.

[25] Nugroho, A. (2010). Rekayasa Perangkat Lunak Berorientasi Objek Dengan Metode USDP. Yogyakarta: Andi.

[26] Sharive. (2013). YII Framework Menguasai PHP Terbaik. Yogyakarta: Lokomedia.

[27] Pasaribu, Johni S. (2019). Information System Based On Website Application As Implementation Of Disclosure Of Public Information At Diskominfo Kabupaten Bandung. Journal Of Physics: Conference Series, 1(179), 3. 